\title{
Pre-slaughter cattle welfare indicators for use in commercial abattoirs with voluntary monitoring systems: A systematic review
}

\author{
Natyieli Losada-Espinosa, Morris Villarroel, Gustavo A. María, Genaro C. Miranda-de la Lama
}

\begin{abstract}
A B S T R A C T
Animal welfare has become an important subject of public, economic and political concern, leading to the need to validate indicators that are feasible to use at abattoirs. A systematic review was carried out, which identified 72 cattle welfare indicators (CWI) that were classified into four categories (physiological, morphometric, behavioral and meat quality). Their validity and feasibility for use in abattoirs were evaluated as potential measures of cattle welfare during transportation to the abattoir and at the abattoir itself. Several highly valid indicators were identified that are useful to assess welfare at abattoirs, including body condition score, humananimal interactions, vocalizations, falling, carcass bruising, and meat $\mathrm{pH}$. In addition, some intermediate valid indicators are useful and should be investigated further. Information along the food chain could be used systematically to provide a basis for a more-risk-based meat inspection. An integrated system based on the use of key indicators defined for each inspection step with the setting of alarm thresholds could be implemented.
\end{abstract}

\section{Introduction}

Throughout pre-slaughter operations, animals may be challenged by stress-inducing situations, i.e., when they cannot adapt behaviorally or physiologically to environmental or physical challenges (Terlouw, 2015). Those challenges perturb homeostasis and an adaptive response is activated in an attempt to restore balance (King et al., 2006). First, physiological responses associated with emotional reactivity (heart rate and respiratory frequency) are triggered, followed by behavioral changes (Van de Water, Verjans, \& Geers, 2003; Averós, Martín, Riu, Serratosa, \& Gosálvez, 2008; Bourguet et al., 2010; Pighin et al., 2013). Then, the activation of the hypothalamic-pituitary-adrenal axis (HPA) and the release of corticotropin-releasing hormone (CRH) activate the sympatho-adrenal component of the autonomic response increasing cortisol levels (Ferguson \& Warner, 2008; Hemsworth et al., 2011; Romero, Uribe-Velásquez, Sánchez, Rayas-Amor, \& Miranda-de la Lama, 2017). The adaptation process redirects energy from production to adaptation. Catecholamine release induces hypophagia and weight loss by its effects on the liver and on white and brown adipose tissue (Rabasa \& Dickson, 2016). In consequence, if the stress response is strong enough, production and meat quality will be affected (Grandin \& Shivley, 2015), causing major economic losses to the industry. Overall, the poorer the welfare of the animals is, the greater the economic losses will be (Ingenbleek et al., 2013).

Significant depletion of muscle glycogen reserves pre-slaughter has a profound and well documented effect on several key meat quality attributes such as ultimate $\mathrm{pH}$, tenderness, color, water-holding capacity and sensory indicators (Van de Water et al., 2003; María, Villarroel, Sañudo, Olleta, \& Gebresenbet, 2003; Mounier, Dubroeucq, Andanson, \& Veissier, 2006; Tadich, Gallo, Bustamante, Schwerter, \& van Schaik, 2005). Additionally, Rostagno (2009) shows that stress can have a significant deleterious effect on food safety (an aspect of maximum consumer concern), providing evidence that links stress with pathogen load and shedding in farm animals, although the mechanisms underlying this effect have not been fully elucidated. Extensive research, both under experimental and commercial conditions, has shown that handling of livestock can markedly affect their stress physiology and productivity (Hemsworth et al., 2011). To understand the causes and consequences of stress at slaughter, various studies have been conducted under controlled conditions to evaluate reactions to specific 
procedures (Bourguet, Deiss, Cohen Tannugi, \& Terlouw, 2011). Field studies provide useful information about the effect of commercial environments and are particularly valuable where it is not possible to simulate all factors present in the environment within a controlled experiment (Jarvis, Harrington, \& Cockram, 1996). Both approaches are necessary to understand how animals react to different aspects of pre-slaughter procedures (Bourguet et al., 2011). The pre-slaughter phase includes the conditions and practices between the home stall and the stunning box at the abattoir (Ferguson \& Warner, 2008). During this period, animals can be exposed to a range of challenging stimuli (Ljungberg, Gebresenbet, \& Aradom, 2007), making it difficult to determine which procedures contribute significantly to their stress status (Bourguet et al., 2010). Measurements of impaired biological functioning, particularly those connected to decreased health and increased physiological stress responses, can provide good corroborating evidence that welfare is compromised (Duncan, 2005). In this context, valid, feasible and easy to assess indicators are fundamental to help make it more auditable for producers and more transparent for consumers (Miranda-de la Lama et al., 2017).

Government legislation, have traditionally been the main method for ensuring or improving farm animal welfare (Bennett, 1997). Nevertheless, animal production systems which promote higher standards of animal welfare are believed to lead to higher environmental and financial costs, which will ultimately be passed onto the consumer unless subsidies or tax breaks are put in place for producers. Marketbased solutions are reflected by the increase in the number of private standards introduced with many companies developing voluntary welfare monitoring systems, that ensure that producers and consumers do not have a price out of the market if any additional costs are transmitted through the supply chain (Clark, Stewart, Panzone, Kyriazakis, \& Frewer, 2017). Voluntary monitoring systems, can be defined as the systematic (continuous or repeated) measurement, collection, collation, analysis, interpretation, and timely dissemination of animal-health and welfare data from defined populations (CorreiaGomes et al., 2017). For such monitoring, animal-based welfare indicators are considered the most valid, because the animals themselves are assessed (Llonch, King, Clarke, Downes, \& Green, 2015). But a wide range of CWI should be considered when interpreting the responses of animals to variations in their environment, including indirect ones related to product quality. On-farm welfare assessments are the main method for assessing cattle welfare, but those assessments are labor intensive, time consuming and may even increase disease transmission within and between farms (Dalmau, Temple, Rodríguez, Llonch, \& Velarde, 2009). Post-mortem meat inspection has the potential to more easily detect diseases and certain welfare conditions which may not be apparent during ante-mortem inspection of the animal upon arrival to the abattoir (Vial \& Reist, 2014; Grandin, 2017). In the past, welfare audits have been developed and tested as instruments for research or commercial requirements for documenting animal welfare at the abattoir level. However, these audits are not meant to be used routinely in most veterinary surveillance systems around the world (Kristensen, Stoier, Würtz, \& Hinrichsen, 2014). Therefore, there is an increased international trend to incorporate welfare indicators during meat inspection at abattoirs as a voluntary monitoring tool for cattle health (Harley, More, Boyle, O'Connell, \& Hanlon, 2012; van Staaveren et al., 2017). Likewise, a relatively new idea has been proposed known as "iceberg" or "key" indicators. In their 2009 report, the Farm Animal Welfare Council (FAWC) suggested using iceberg indicators in abattoirs as a means of assessing and ensuring overall animal welfare, from the farm of origin to the abattoir (van Staaveren et al., 2017). The aim of this paper is to review current knowledge about CWI while assessing their validity (that they measure what they intend to measure) and feasibility (in terms of speed, cost and effect on normal operating procedures) of use in abattoirs. The indicators were classified into four categories (physiological, morphometric, behavioral and product quality) and qualitatively evaluated based on published literature.

\section{Materials and methods}

The main aim of this review is to assess indicators that scientists and other professionals currently use to measure cattle welfare and their possible application in abattoirs. Most inspections at abattoirs are focused on meat quality peri -or post-mortem in order to protect public health by ensuring food safety. Nevertheless, there is increasing interest in incorporating pre-mortem CWI that could indicate underlying problems (van Staaveren et al., 2017).

\subsection{Search criteria and strategy}

We performed a systematic review of scientific literature published between January 1995 to October 2016 based on methodology developed by Llonch et al. (2015), only including published and peer reviewed journal articles regarding the welfare assessment of cattle (calves, steers, heifers, cows and bulls). Searches were performed using the same search terms in four search engines: (1) PubMed; (2) ScienceDirect; (3) Scopus; and (4) Scielo. The search terms used (including all titles, abstracts and keywords) were: cattle OR beef cattle AND welfare $O R$ 'animal welfare' AND transport OR lairage $O R$ stun $O R$ slaughter OR abattoir AND 'meat quality' AND PUBYEAR > 1994. Records from the databases were exported directly to EndNote, including articles in English or Spanish. Duplicates and documents not directly related to cattle welfare were removed.

\subsection{Criteria for selection of animal-based welfare indicators}

A total of 85 articles were retrieved and read to identify animalbased and product-quality based indicators associated with cattle welfare. Related indicators assessing the same welfare problem were combined to give 72 separate indicators (Tables 1 to 4). Each indicator was then allocated to a category of measurement (physiological, morphometric, behavioral and product quality). The validity and feasibility of measuring each indicator in an abattoir was categorized as high, intermediate or low, according to Llonch et al. (2015). High validity indicators were those validated in previous research through a large number of articles, which in turn had internal (e.g. sampling, measures and procedures) and external (inferences) validity, making them prone to be considered as valid indicators. Intermediate validity indicators were those that did not necessarily indicate poor welfare (e.g. body condition score). Low validity indicators were suggested but lack evidence that they actually assess welfare. Indicators with high feasibility were those that could be recorded in abattoirs, regardless of the number of animals, the space available for the animals, or the speed of the processing line. Medium feasibility indicators were those that needed special requirements (e.g. extra space or time) for appropriate assessment. Low feasibility indicators were those that could not be routinely assessed in commercial abattoirs. Where an indicator was defined as having high validity in its original setting, but did not appear likely to be valid or feasible when measured in an abattoir, we considered the possible use of intermediate validity indicators with high feasibility, or alternative novel technologies.

\section{Results}

The assessment of current scientific literature provided 72 indicators of cattle welfare, separated by category and feasibility in Tables 1 to 4, for a total of 22 physiological, 2 morphometric, 32 behavioral and 15 product quality indicators. Most of the studies (85\%) were performed under commercial conditions, with only a few experimental ones (Apple, 1999; Apple et al., 1999; Lensink et al., 2000; María et al., 2003; King et al., 2006; Schwartzkopf-Genswein et al., 2007; Bourguet et al., 2010; Burdick et al., 2010; del Campo, Brito, Soares de Lima, Hernández, \& Montossi, 2010; Alende et al., 2014; Emenheiser et al., 2014). 


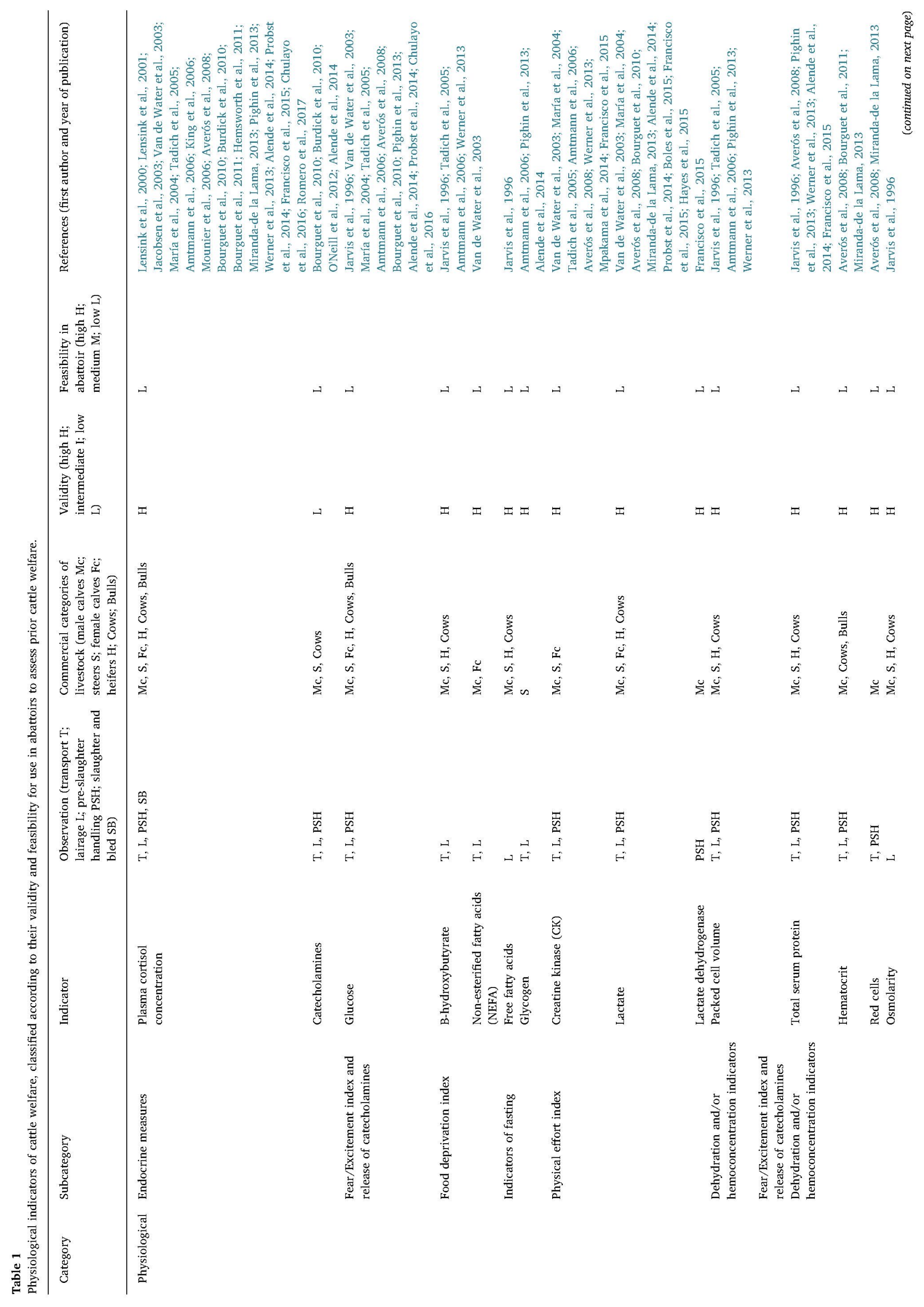




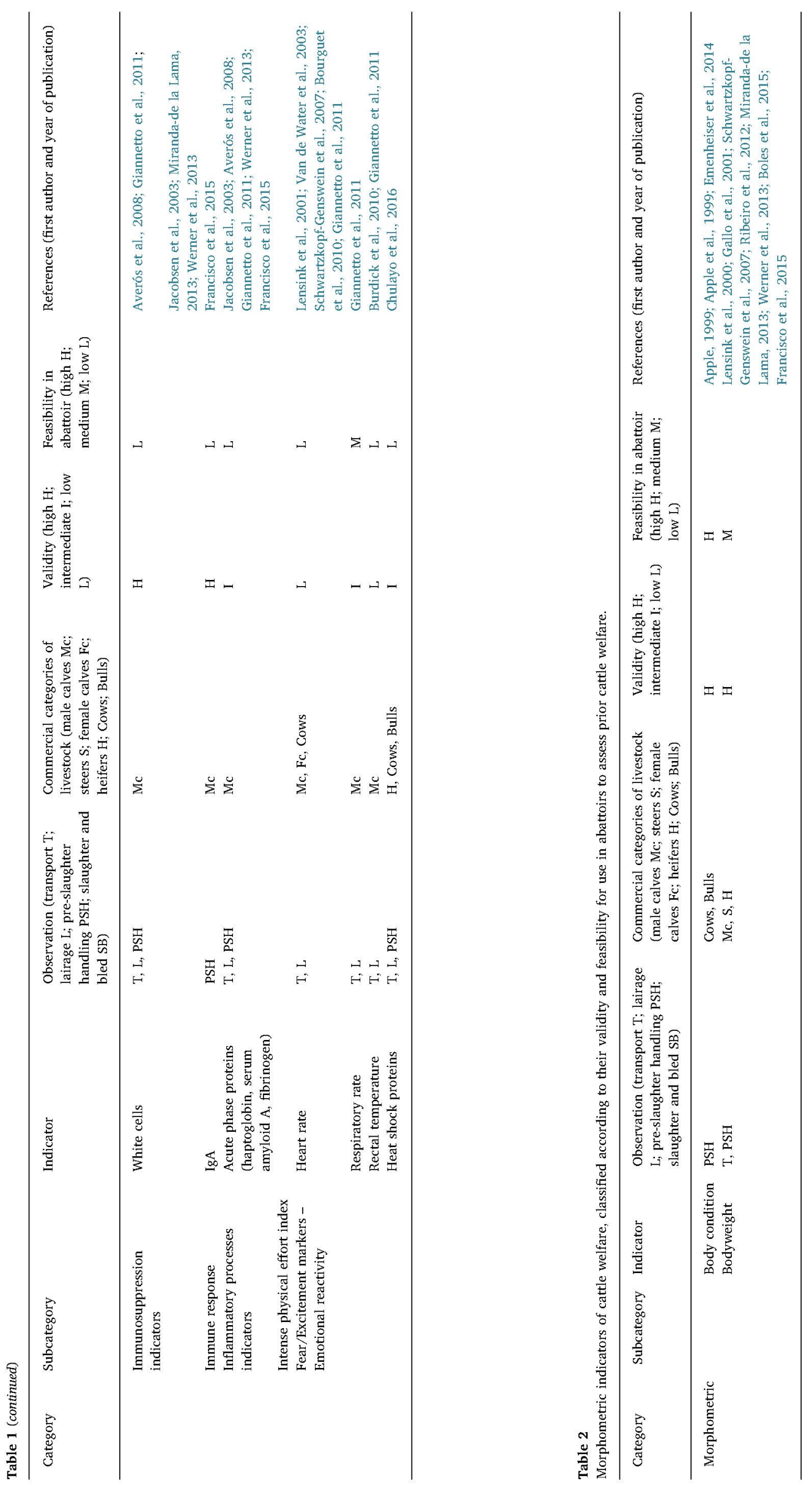




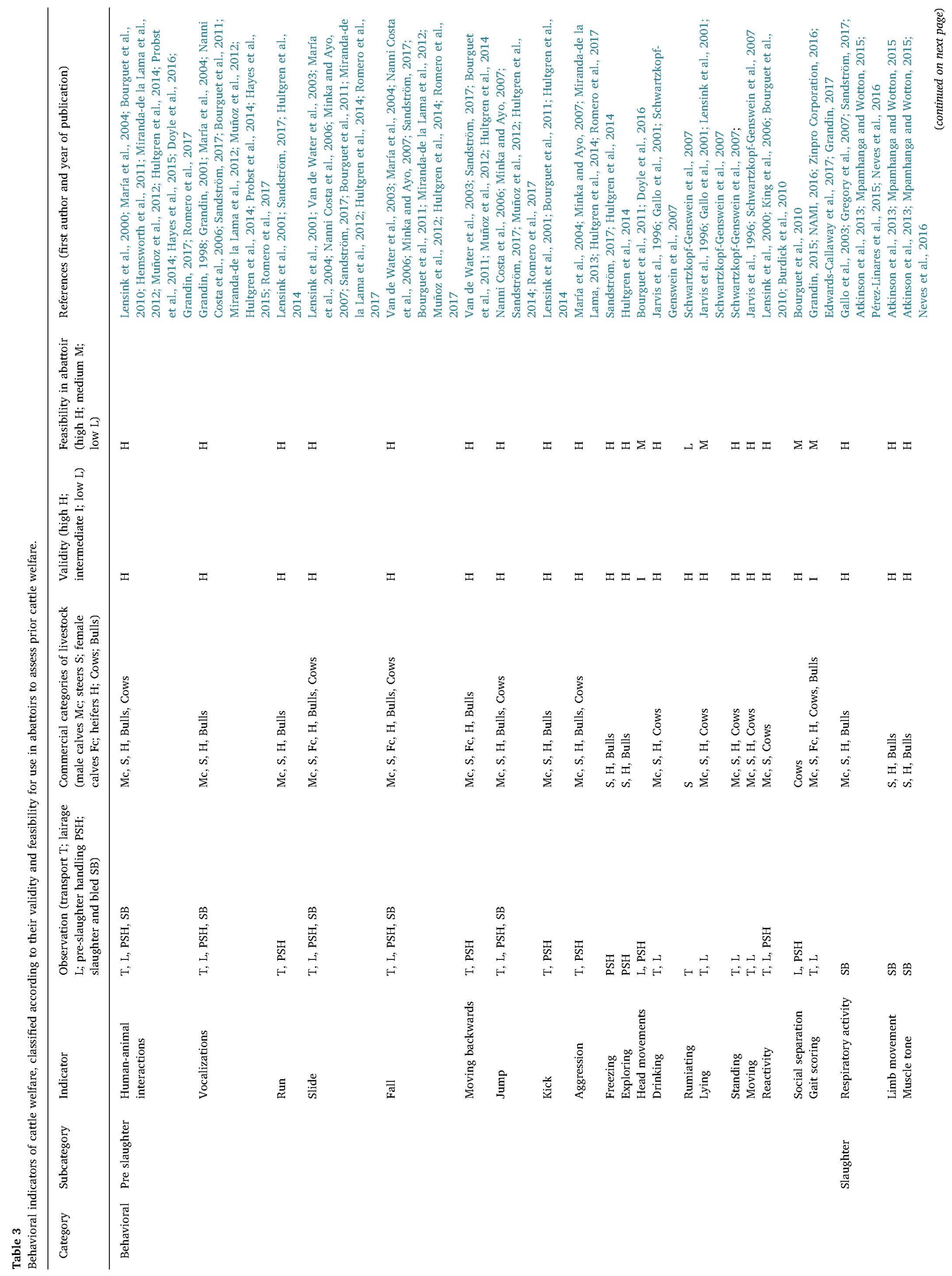




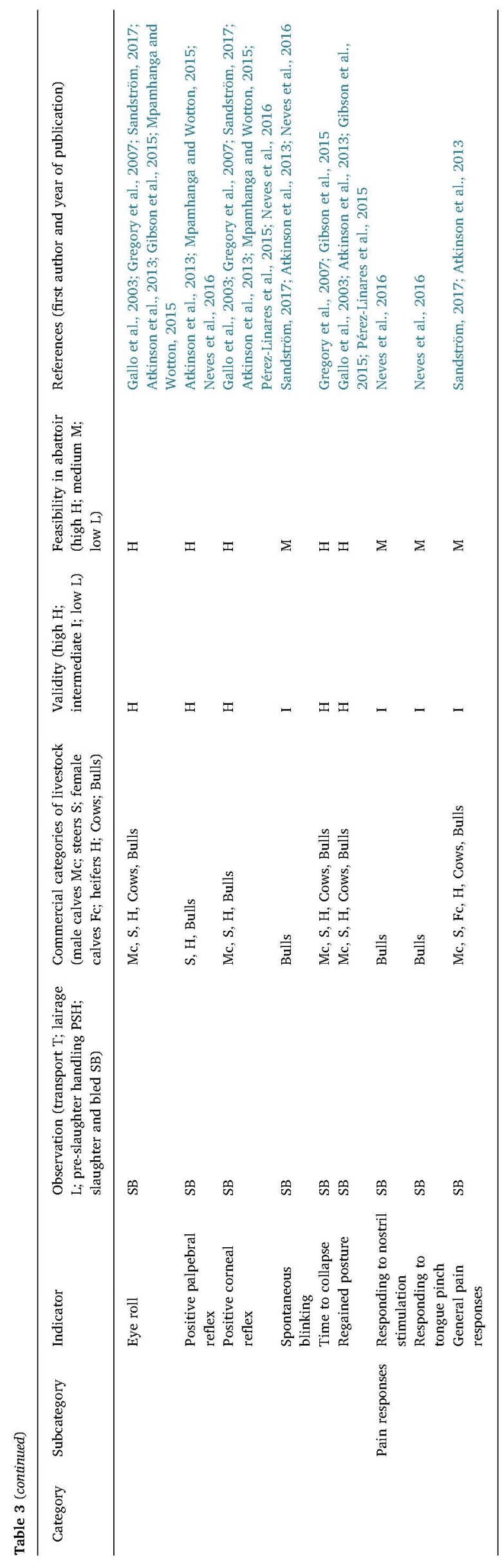

Table 1 shows all the physiological indicators. Of the 10 subcategories that made up this classification, dehydration and/or hemoconcentration indicators (packed cell volume, total serum protein, hematocrit, red cells and osmolarity), physical effort indices (CK, lactate, lactate dehydrogenase and acute phase proteins), and fear/excitation and emotional reactivity markers (heart rate, respiratory rate, rectal temperature and heat shock proteins), stood out in the number of indicators used to measure these subcategories ( $23 \%, 18 \%$ and $18 \%$ of the total number of indicators, respectively). However, plasma cortisol concentrations (endocrine measure), glucose (fear/excitement index and also related with the release of catecholamines) and lactate (a physical effort index) were the most used indicators among the authors corresponding to this category (83\%). With respect to the morphometric category, $73 \%$ of the publications (concerning this category) used liveweight as the main morphometric indicator (Table 2).

Among behavioral indicators (Table 3), 63\% corresponded to the pre-slaughter subcategory, $28 \%$ to the slaughter subcategory and only $9 \%$ to the pain responses subcategory. Human-animal interactions and vocalizations were the most common indicators during pre-slaughter ( $48 \%$ and $44 \%$ of authors corresponding to this category, respectively), and respiratory activity and positive corneal reflex in the slaughter subcategory ( $78 \%$ of authors corresponding to this category). Finally, among all the product quality indicators (Table 4), $64 \%$ were instrumental, $29 \%$ sensorial and $7 \%$ related to carcass quality. The indicators most used by the authors of this category were $\mathrm{pH}$, color and bruises (68\%, $47 \%$ and $34 \%$, respectively).

\section{Discussion}

This review focused on identifying the main CWI used in international research, especially under commercial conditions, and assessing their validity and feasibility to promote their use at abattoirs. Systematically collected data are essential for the accurate description of health-hazard occurrence and can then contribute to the planning, implementation, and evaluation of risk-mitigation actions (Hoinville et al., 2013). Hence, animal welfare surveillance activities may provide a framework that not only enables the timely identification of hazards and threats, but also suggests approaches that either support or drive different risk management strategies to be adopted by the public and private sectors. For example, these may comprise the internalisation of risk by the private sector, stated risk mitigation and management initiatives, or complementary partnership approaches (Irivine, 2015).

\subsection{Physiological indicators}

Different authors have used blood parameters to assess the stress response of cattle to handling and transport (Villarroel, María, Sañudo, Olleta, and Gebresenbet, 2003b; Tadich, Gallo, Brito, \& Broom, 2009). Cortisol, despite its variability and short half-life, is still one of the most used indicators, followed by packed-cell-volume (Jarvis et al., 1996; Tadich et al., 2005; Pighin et al., 2013), glucose (Van de Water et al., 2003; Averós et al., 2008; Bourguet et al., 2010; Alende et al., 2014), lactate dehydrogenase (LDH), insulin, free fatty acids (Jarvis et al, 1996), plasma activity of creatine kinase (CK), B-hydroxybutyrate (Broom, 2003; Tadich et al., 2005). More recently, haptoglobin and pigmap, a major acute phase proteins, have also been used as an indicator of poor welfare (Piñeiro et al., 2007; Averós et al., 2008; Giannetto et al., 2011; Werner et al., 2013; Francisco et al., 2015). It is a basic tenet of science (often overlooked) that measures should be adequately validated before use. This has not been done for many of the behavioral, physiological and immune measures being used (Rushen, 2003).

In some countries, governments have commissioned small periodic inspections using indicators such as cortisol, lactate and glucose (Romero et al., 2017). Nevertheless, it is not always easy to interpret cortisol levels as an indicator of the response of animals to short and long-term challenges. Adrenal cortical activity is not confined to 


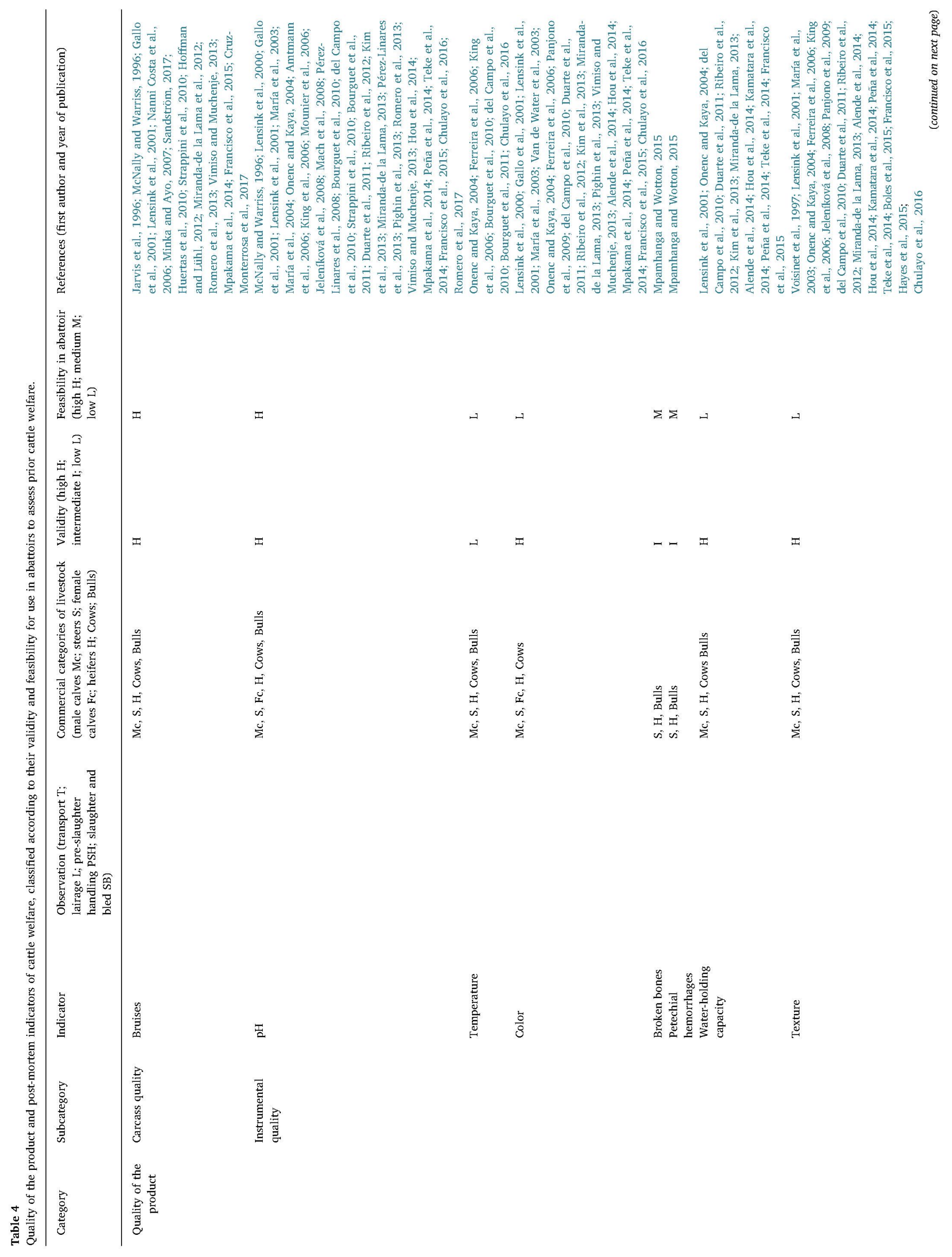


adverse conditions as it occurs during courtship, mating and active food acquisition, none of which could be described as activities with adverse effects on the individual (Broom, 1988). Moreover, other factors such as sampling, movement restriction, lactation, milking, degree of habituation, hormones, infections, as well as endotoxins, can also affect cortisol levels (Sapolsky, Romero, \& Munck, 2000; Trevisi \& Bertoni, 2009; Blanco, Casasús, \& Palacio, 2009). Normally several samples are required over time to take into account peaks and troughs and diurnal variation (Broom, 1988; Shaw \& Tume, 1992). An enzyme generally utilized as an indicator of physical stress and/or muscle damage in animal production is creatine kinase (CK) (Minka \& Ayo, 2009; Mpakama, Chulayo, \& Muchenje, 2014; Simova, Voslarova, Vecerek, Passantino, \& Bedanova, 2016). The activity of CK rises apparently as a result of an increase in the permeability of the muscle membranes induced by capture, loading and transportation (Mpakama et al., 2014). Transportation for several hours is a physical demanding factor; animals have to maintain balance and the contact between animals produces fatigue and bruising, affecting the permeability of the membranes and the liberation of the enzymes into the blood. In some experiments when the animal welfare transport order was abided with, the rise in concentration of CK in the blood was either minimal or completely absent, signifying low level of tissue damage (Hill, McManus, Brown, Playford, \& Noble, 2000; Minka \& Ayo, 2009). Although it is a highly used enzyme in research, it has limitations too (to be mentioned later). Each individual animal has alternative methods of coping with adversity, so using only one physiological measure of response may give the impression that most animals are not stressed (Broom, 1988; Dawkins, 1998; Galindo \& Manteca, 2012). Physiological indicators are not used consistently in slaughterhouses because they are expensive, invasive, and require additional handling of the samples (Llonch et al., 2015). On the other hand, physiological indicators may not always be accurate indicators of animal welfare; the metabolism for the synthesis of some hormones (e.g. catecholamines) and the physiological status of animals per se should also be considered (O'Neill, Webb, Frylinck, \& Strydom, 2012; Chulayo \& Muchenje, 2015).

It is clear that all criteria used to assess welfare rely on showing some evidence of change. Change per se is not an indicator of a change in welfare since animals are continually adjusting their physiology to maintain homeostasis (Miranda-de la Lama et al., 2012). Obviously their welfare is not in a continual state of flux either, because of these continued adjustments. The important question for welfare research in both disciplines is "At what level of change is welfare at risk?" (Barnett \& Hemsworth, 1990). We believe that it is important to establish clear cut-off values for each criteria for each livestock species. Furthermore, there has been a tendency in the past to rely too much on physiological, immune and behavioral measures of welfare that have not adequately been validated, and without considering health problems, which are some of the major threats to farm animal welfare (Rushen, 2003). On the other hand, extremely stress sensitive indicators may not be useful in practice, as has been the case with certain indicators such as the acute phase enzymes (e.g. Pig-Map or Haptoglobine) triggered by stressful situations due to absolutely normal management practices or by routine farm vaccination programs. The sensitivity of an indicator should be such that it is possible to reliably detect stressful situations that lead to significant suffering for animals, avoiding unnecessary alarms based on normal metabolic changes.

It seems logical that veterinarians should be heavily involved in animal welfare, but they have been historically under-represented, particularly in the English-speaking part of the world (Rushen, 2003). This has led to an underestimation of the importance of health problems as a source of animal welfare problems, and an underuse of the incidence of health problems as welfare indicators, despite early recognition of the importance of health problems for animal welfare, as reported by Broom (1986). It is clear that evaluating animal welfare is a complex task and that there is no simple and unique measure (Rushen, 2003). Consequently its evaluation must be approached from multiple 
perspectives, embracing both the environment where the animal lives, the animal itself and its production. In choosing which physiological variables best measure welfare, we should not rely too heavily on "stress hormones", as they may not be as specific to states of unpleasant motivation as we might have thought (Dawkins, 1998). As mentioned above, physiological changes can also be measured through heart and ventilation rates, as well as body temperature, which can change according to activity level and preparation for emergency action. In both situations, those variables provide information about how hard the animal is working to cope with a situation (Broom, 1991) and have often been used when analysing the effects of transport and lairage (Lensink, Fernandez, Cozzi, Florand, \& Veissier, 2001; Van de Water et al., 2003; Schwartzkopf-Genswein et al., 2007; Bourguet et al., 2010; Burdick et al., 2010; Giannetto et al., 2011). At slaughter, however, measuring the heart or respiratory rate is not feasible, although the latter could be calculated indirectly based on body temperature (using a thermographic camera for example). Stressors can cause a short-lived increase in core body temperature in ruminants, which can be measured easily (Pascual-Alonso et al., 2017). There have been a number of recent studies using Infra-Red Thermography (IRT) for disease and welfare surveillance of livestock. Infra-Red Thermography involves using an infrared camera on animals in a pen, and then identifying the surface temperature of some part of the animal from the sensed wavelengths (Yazdanbakhsh, Zhou, \& Dick, 2017). Using the surface of the eye is a common choice for fever surveillance; anatomically it should correlate well with the animal's core temperature, and be less affected by ambient temperatures (Okada, Takemura, \& Sato, 2013). Along those lines, Burdick et al. (2010) found that 'temperamental' bulls may exhibit a higher temperature and respiratory response to stressors compared with 'calm' and 'intermediate' bulls.

\subsection{Morphometric indicators}

In beef cattle, common indicators of undernutrition are bodyweight or body condition score (BCS), although their use at slaughter level is limited since they vary in terms of animal age, sex and breed, mature size, stage of pregnancy or gut fill (Nicholson \& Sayers, 1987; Morris, Kenyon, \& Burnham, 2002; Coopman, De Smet, Laevens, Van Zeveren, \& Duchateau, 2009; Tebug, et al., 2016; Wangchuk, Wangdi, \& Mindu, 2017). Normally, at the slaughterhouse, weight loss is calculated in groups or batches, not individually. Consequently, BCS is generally used as a measure of nutritional status. Although BCS does not indicate current state of hunger, it does provide information on long-term nutritional status (Phythian, Hughes, Michalopoulou, Cripps, \& Duncan, 2012). Usually the BCS estimates mobilization of energy reserves of cattle or the degree of fatness or thinness using a 5-point scale $(0=$ thinnest, $5=$ fattest). Other scoring ranges use the 1-9 scale, in the USA, and the 0-2 scale proposed by the Welfare Quality Project (Corah, 1989; Welfare Quality, 2009).

According to Morris et al. (2002), the condition score technique is easily learned, requires no equipment and, although somewhat subjective, provides reliable results when related to subcutaneous fat cover. Apple (1999) mentioned that BCS can be useful to both cow-calf producers and slaughter-cow processors in making market decisions. Measuring BCS can be considered highly feasible, however, some scores have too many categories and suffer from inter-observer variability (Grandin, 2017). Halachmi, Klopcic, Polak, Roberts, \& Bewley (2013) report that results depend on the person scoring, familiarity with the cows, and consistency between scoring periods, suggesting the use of a device for automatic (objective) monitoring of body condition, such as thermographic cameras or ultrasound scanning. However, the costs of equipment and consultants may only make it feasible for larger commercial breeding flocks, for genetic selection programs and for production systems where carcass attributes are important in classification (McGregor, 2017). In developing economies and in remote regions where new technologies are not available, low cost subjective evaluation methods such as subjective BCS are the only alternative. Body Condition Score can also undergo sudden changes, such as during the productive cycle of the cow. That may produce a high-risk metabolic state (negative energy balance) since large amounts of body reserves are mobilized by the animal and must be metabolized, making it more prone to the onset of metabolic diseases.

\subsection{Behavioral indicators}

Slaughter plants are designed based on conventional architectural criteria, such as space optimization or the facilitation of human activities, but do not normally consider the behavioral needs of animals (Miranda-de la Lama et al., 2012). Complete measurements of animal welfare require observations from unloading to unconsciousness, including at the unloading bay, during lairage, moving the cattle to the stun box and at bleeding out (Hultgren, Wiberg, Berg, Cvek, \& Lunner Kolstrup, 2014). Reactions to certain aspects of slaughter procedures could have consequences for subsequent slaughter stages, so improving one stage may have positive effects on subsequent stages (Bourguet et al., 2011). For cattle, loading and unloading are often more stressful than the journey itself; however, there are no regulations that define the appropriate conditions or time limits for these procedures (María, Villarroel, Chacón, \& Gebresenbet, 2004). On the other hand, it should be taken into account that both the facilities available during those stages and the handling by the stockpersons will also influence animal behaviour. Several authors suggest the measurement of falls, aggression/fight, slips, jumps, baulks, reversing, mounting and vocalizations (Van de Water et al., 2003; Minka \& Ayo, 2007; Bourguet et al., 2011; Hultgren et al., 2014), since they are indicators (events) associated with fear-related behavioral responses and might reflect the efficiency with which the animals are handled upon arriving at the slaughter plant (Hemsworth et al., 2011; Miranda-de la Lama et al., 2012). Loading and unloading conditions will influence the quality of lairage time; however, lairage under poor conditions will also affect animal behaviour.

Grandin (2017) mentions the wide variation among cattle behaviour during lairage, based on reports by abattoir personnel; cattle can be difficult or easy to move and the former are more likely to be abused. That may be explained by differences in emotional reactivity, i.e., the tendency to show pronounced reactions to different fear-inducing situations (Bourguet et al., 2010). The tests used to evaluate animal fear, in the human-animal relationship (HAR), can divided into three categories: 1) evaluation of the reactions to the presence of a stationary person, 2) evaluation of the reactions to a person in movement, and 3) reactions to management (Lensink et al., 2001; Bourguet et al., 2010; Waiblinger, Menke, Korff, \& Bucher, 2004). At the abattoir, these tests should normally be quite brief (Hultgren et al., 2014) and carried out on groups cattle, to eliminate stress due to social isolation, which can affect the results. This methodology has been useful to identify problems related to the design of the slaughter plants, deficiencies in selection and training of personnel responsible, staff attitude and the emotional state of the animals evaluated (Hemsworth, 2003; Hultgren et al., 2014; Romero et al., 2017).

The drive to the stunning box can be stressful, depending on the length and design of the chute and the quality of the HAR. Vocalizations due to electric prod use, balking, refusing to move, backing up and turning around are indicators that can be compared between different producers animals (Grandin, 2017). Electric goads are very stressful for cattle. According to Grandin (2010), the percentage of animals moved with an electric goad is one of five measures recorded by private industry and some governments when auditing animal welfare at slaughter plants. Previous studies have shown that increased handler interaction is correlated with an increased physiological stress response in cattle, and that tactile interactions and high-pitched or loud noises are associated with fear or stress cattle (Breuer, Hemsworth, Barnett, Matthews, \& Coleman, 2000; Weeks, 2008; Hemsworth et al., 2011). Human-generated or artificial auditory interactions have also been 
shown to generate increased heart rate and movement in cattle as well (Waynert, Stookey, Schwartzkopf-Genswein, Watts, \& Waltz, 1999) Objective handler-behaviour observations used by several authors include tactile interactions (e.g. pushing, hitting and electric prod), auditory interactions (e.g. talking, shouting, whistling and the use of artificial noises, such as banging of pen fittings), visual interactions (e.g. waving arms or flapping objects) and contact with sensitive areas (Hemsworth et al., 2011; Hultgren et al., 2014; Doyle et al., 2016). Doyle et al. (2016) also developed a subjective assessment that evaluates the relationship between stockpersons and animals. Although this scale may be a useful way to record handler behaviour and provide a fast and effective technique for auditing, further research is needed to confirm its reliability. The quality of handling during the driving of the animals will influence the effectiveness of the stunning. Probst et al. (2014), Bourguet et al. (2011) and Romero et al. (2017) all mention that the ease with which animals are driven to the stunning box can be associated with the number of stuns required. The number of electrical prods may render subsequent stunning more difficult, or alternatively, animals that were reactive when introduced into the stunning box, could be also reactive during stunning. The stress status of the operator may play a role too (Hemsworth, 2003). Vocalizations during stunning are a useful indicator since they are related to inefficient gun calibration, lack of maintenance, deficient personnel training, presence of very excited cattle and the excessive pressure of the head brace (Grandin, 2010). As mentioned above, vocalizations in the stunning box are indicative of reactivity, illustrating that animals should be stunned without delay (Muñoz, Strappini, \& Gallo, 2012). Finally, indicators such as slips, reversals, falls and jumps could also be considered when designing stunning boxes (Gallo, Teuber, Gartes, Uribe, \& Grandin, 2003).

The types of behavioral observations used to assess pain can be divided into subjective or objective measures. Subjective scoring systems have been particularly popular in the veterinary literature because they are considered relatively easy to apply in a clinical setting. A wellknown example for dairy cattle is gait scoring to assess lameness (Rushen, de Pasillé, von Keyserlingk, \& Weary, 2008). Cattle mobility scoring is becoming one of the widely accepted method of assessing potential welfare effects. But no such tool existed two years ago for finished cattle; however, it is important to mention that several lameness studies have been conducted on farms, showing that it is a serious welfare problem (von Keyserlingk, Barrientos, Ito, Galo, \& Weary, 2012; Cook, Hess, Foy, Bennett, \& Brotzman, 2016). Mobility scoring is an animal-based measure. Typically it involves using a scoring system with a four point severity scale that assesses cattle mobility (gait or movement) following the pattern of movement of the limbs of cattle during locomotion (Grandin, 2015; NAMI, 2016; Zinpro Corporation, 2016). Although finished cattle can certainly suffer from lameness (with significant economic impacts for feedyards), impaired mobility has been relatively unstudied in finished cattle compared with dairy cattle (Edwards-Callaway, Calvo-Lorenzo, Scanga, \& Grandin, 2017). Lame animals that have difficulty walking can be assessed easily when they are unloaded from the trucks at the abattoir. To facilitate comparisons between slaughter plants, both producers and the meat industry should choose a common scoring tool (Grandin, 2017). Some of the challenges associated with large-scale cattle mobility scoring are consistency and subjectivity of mobility scoring, the environment in which cattle are evaluated, and the speed at which cattle must be evaluated in commercial environments (Edwards-Callaway et al., 2017). Due to this, some researchers have proposed to using the incidence of hoof problems and/or an automated monitoring system (e.g. cameras that detect lameness problems or fatigued animals -no ambulatory animals-) (Thomson, Loneragan, Henningson, Ensley, \& Bawa, 2015) as a more reliable approach than gait analysis. However, there is little standardization regarding hoof lesion scoring (Rushen et al., 2008; van Staaveren et al., 2017).

Some behavioral indicators are thought to be more valid than others
(Llonch et al., 2015). While having the advantage of being non-invasive, some are more costly in terms of time required by the evaluator (María, 2017). Since the abattoir is a novel environment for cattle, as compared to the farm, behavioral CWI can only be considered to be valid at the time of inspection at the abattoir, without providing valid information about prior welfare (Visser et al., 2001). On the other hand, cattle behaviour at the abattoir could be also influenced by individual characteristics like breed (Minka \& Ayo, 2007; Hoffman \& Lühl, 2012; Sant'Anna \& Paranhos da Costa, 2013), sex (Probst et al., 2014; Hoffman \& Lühl, 2012), age (Hoffman \& Lühl, 2012; Hultgren et al., 2014) and earlier experience (Lensink et al., 2000; Lensink et al., 2001; King et al., 2006; Bourguet et al., 2010; Pighin et al., 2013).

\subsection{Product quality and post mortem indicators}

Several studies have shown that even slight defects in beef quality indicate suffering ante-mortem, as corroborated by physiological, plasmatic or behavioral indicators. However, a lack of meat quality defects does not assure an absence of suffering before slaughter (María, 2008). In terms of carcass and meat quality, the most common welfare indicator associated with improving handling practices is skin lesions, such as scrapes and bruises, potential objective indicators of welfare. A bruise is defined as a visible extravasation of erythrocytes in the subcutis and surrounding tissue, following trauma to the body by the impact of a blunt instrument (Pilling, Vanezis, Perrett, \& Johnston, 2010). The skin surface is intact but the walls of veins, venules and small arteries are torn, so blood leaks into the surrounding tissue (Barington \& Jensen, 2016).

Recording carcass bruises at the abattoir may have significant potential as a resource for surveillance of welfare problems in livestock (Correia-Gomes et al., 2016). Bruises are highly valid and feasible indicators of animal welfare, indicating basic failures in the pre-slaughter logistic chain. They can help to identify the source of problems, such as electric prod usage, protruding objects or rough edges, falling, abusive stockman-ship, social mixing, or drop gates (Miranda-de la Lama et al., 2012). First it is important to establish a baseline (distinguishing between accidental and avoidable lesions), upon which improvements can be made and then to standardize assessment. To improve accuracy, the same person should do the scoring at the abattoir (Grandin, 2017). In practical terms, bruises can be separated into two categories: fresh bruises and old bruises (that occurred before lairage; Grandin, 2017). Determining the age of the bruise is important in order to associate it with pre-slaughter handling, but if transport and lairage occurs within $12 \mathrm{~h}$, it is very difficult tell when a bruise was inflicted (Strappini, Metz, Gallo, \& Kemp, 2009). Bruises older than $18 \mathrm{~h}$ are more yellow than fresh bruises (Langlois, 2007). Approximately one hour after a bruise is inflicted, changes in its gross appearance depend on the force of impact, which will affect its severity and amount of necrotic muscle tissue (Barington \& Jensen, 2016). Several bovine carcass scores have been developed worldwide to be used at slaughterhouses for commercial purposes (Strappini et al., 2009). The Australian Carcass Bruises Scoring System (ACBSS) devised by Anderson and Horder (1979) classifies the severity of bruising according to the surface area of the lesion in three groups: 'slight', 'medium' and heavy'. The Finnish Meat Research Institute has developed a carcass-bruising evaluation system based on the color and severity of the trauma (Honkavaara, Rintasalo, Ylonen, \& Pudas, 2003). While in several South American countries (Argentina, Brazil, Chile and Uruguay), a bruising grading classification is currently used which is based on the severity of the bruise and the tissues affected in the injured area. However, the use of this grading system is only compulsory in Chile (CHILE, 1994; [INN] Instituto Nacional de Normalización, Chile, 2002). Although current bruisingscoring systems in the slaughterhouses are useful for learning about the prevalence of bruises on slaughtered cattle, epidemiological analyses are required to obtain accurate information on risk factors for the occurrence of bruises and the likelihood of presumed causes (Strappini 
et al., 2009).

Stress responses may influence post-mortem muscle metabolism and consequently, meat quality (Bourguet et al., 2010; Hemsworth et al., 2011). At the commercial level, the last $\mathrm{pH}$ measurement taken is one of the most important reference values to measure meat quality and is related to the depletion of glycogen reserves, and the release of lactate caused by stressful handling (Terlouw, 2015). It is also the most commonly used instrumental indicator in studies that evaluate preslaughter handling, because it takes into account metabolic routes and muscle energy stores. Animal transport includes the farms, intermediate points (auction markets, storage centers, classification of logistics centers, health checkpoints, logistical stopovers and resting points) and the slaughter plant (Miranda-De la Lama et al., 2014). In this context, Romero, Uribe-Velásquez, Sánchez, \& Miranda-de la Lama (2013) found that animals from markets or that made stops during the journey had higher $\mathrm{pH}$ levels compared to those transported directly from the farm to the slaughter plant. María et al. (2003) and Ferreira et al. (2006) did not find many significant changes in meat $\mathrm{pH}$ in terms of journeys duration but few effects are noted when stress is mild or animals are in good health. According to Warriss, Kestin, Brown, \& Wilkins (1984) glycogen resources can be restored at lairage, and cattle can recover from physical exhaustion even if they are not fed. On the other hand, Gallo, Espinoza, \& Gasic (2001), Mounier et al. (2006), del Campo et al. (2010) and Teke, Akdag, Ekiz, \& Ugurlu (2014) found that ultimate $\mathrm{pH}$ was lower when lairage was longer. Several authors suggest that the ability of cattle to rest or recover during lairage depends on the environment and the effects of feed and water restriction (Jarvis et al., 1996; Van de Water et al., 2003). Bourguet et al. (2011) report that differences in slaughter procedures and slaughter type (halal vs. conventional) can also influence ultimate $\mathrm{pH}$. Overall, stressors appear to be additive and multiple stressors in the pre-slaughter period will result in a higher ultimate muscle $\mathrm{pH}$ than a single stressor alone (del Campo et al., 2010). Other studies have found that differences in ultimate $\mathrm{pH}$ are due to feeding system, temperament and breed (Lensink et al., 2000; Lensink et al., 2001; Amtmann, Gallo, van Schaik, \& Tadich, 2006; Mounier et al., 2006; Ribeiro et al., 2012; Pighin et al., 2013; Mpakama et al., 2014), commercial category (Mach, Bach, Velarde, \& Devant, 2008; Romero et al., 2013), and bruises (McNally \& Warriss, 1996; Strappini, Frankena, Metz, Gallo, \& Kemp, 2010; Vimiso \& Muchenje, 2013). Hence, ultimate $\mathrm{pH}$ is a valid indicator to measure meat quality, being both reliable and commercially viable, to such the extent that many abattoirs systematically measure meat $\mathrm{pH}$ (María, 2008).

The $\mathrm{pH}$ of the muscle can also affect important commercial characteristics of color and water holding capacity. When the final meat $\mathrm{pH}$ is 5.8-6, the proteins suffer several molecular changes, including the presence of spaces (gaping) that are rapidly filled in with water (greater water retention), and are obstacles for free oxygen transport from the surface to the center of the muscle, with which the myoglobin would be transformed into metmyoglobin, giving a darker color to the meat (Terlouw, 2005). Vimiso \& Muchenje (2013) found a significant negative linear effect of distance, stocking density and transportation duration on color. On the contrary, María et al. (2003) and Van de Water et al. (2003) did not find a major effect of transport on meat color. María et al. (2003) mention that no single factor is responsible for meat discoloration, which is probably due to a combination of factors associated with post-mortem changes. Other factors that have been related to an increase in both the color and the water holding capacity of the meat are the position of the animal inside the livestock vehicle (front vs back) (Van de Water et al., 2003), lairage time (Gallo et al., 2001; del Campo et al., 2010; Teke et al., 2014), stunning method (Onenc \& Kaya, 2004; Kim et al., 2013), temperament of the animals (Voisinet, Grandin, O'Connor, Tatum, \& Deesing, 1997; Lensink et al., 2000; Lensink et al., 2001; King et al., 2006; del Campo et al., 2010; Ribeiro et al., 2012; Miranda-de la Lama et al., 2013; Pighin et al., 2013; Mpakama et al., 2014; Peña et al., 2014; Francisco et al., 2015), and the carcass suspension method (Kamatara et al., 2014; Hou et al., 2014). Measurement of water holding capacity in abattoirs is limited; however, meat color could be evaluated using a color standards.

A pH above 5.8, together with a dark color and high water retention, are characteristics of DFD (dark, firm, dry) meat. That has been related to animal temperament (Voisinet et al., 1997), commercial category (Voisinet et al., 1997; Kreikemeier, Unruh, \& Eck, 1998; Scanga, Belk, Tatum, Grandin, \& Smith, 1998), poor handling during transport (Pérez-Linares et al., 2013; Romero et al., 2017), lairage (high stocking densities and climatic conditions; Kreikemeier et al., 1998; PérezLinares et al., 2013; Teke et al., 2014; Romero et al., 2017), time needed to enter the stunning box (Pérez-Linares et al., 2013), failed stunning (Miranda-de la Lama et al., 2012), and bruises (Romero et al., 2013; Vimiso \& Muchenje, 2013). When borderline dark cutting is determined by visual means, the carcasses classified as "dark" do not necessarily exhibit true DFD characteristics. Therefore, María (2008 and 2017) suggested the possibility of detecting animals prone to this type of defective meats by infrared thermographic cameras (objective evaluation method), which is considered non-invasive. It consists in obtaining a thermal photo of the animal through an infrared camera that will give a characteristic image of candidates for DFD. This system can be installed in abattoirs and will indicate to the operators when an animal (that is going to be slaughtered) can develop abnormal meat. Therefore, it will indicate a convenient wait for its full recovery. However, both the cost of equipment and the recruitment of consultants to use the equipment (or training of staff at the abattoir) may be a limiting factor in economic terms (McGregor, 2017). Thus, a "color sampler" (subjective evaluation method) could be used instead.

The alterations of instrumental quality $(\mathrm{pH}$, color, water retention and texture), also have an influence on the organoleptic properties of meat. María et al. (2003) found differences in sensory quality with respect to transport time in terms of tenderness and overall liking, while Alende et al. (2014) found the same changes in meat but related to longer lairage times. Onene \& Kaya (2004) and Hayes et al. (2015) found that both stunning method and religious slaughter affect beef tenderness. Finally, Miranda-de la Lama et al. (2013) found that scoring by taste panels was affected by the social rank of animals, specifically regarding tenderness and some odors and flavors. Although these indicators are extensively used by researchers, their feasibility of use at abattoirs is low since their evaluation methods are complex to implement commercially.

Acute and chronic acidosis, conditions that follow ingestion of excessive amounts of readily fermented carbohydrates, are prominent production problems for ruminants fed diets rich in concentrate. With acute acidosis, ruminal acidity and osmolality increase markedly as acids and glucose accumulate; these can damage the ruminal and intestinal walls, decrease blood $\mathrm{pH}$, and cause dehydration, laminitis, polioencephalomalacia, and liver abscesses (Owens, Secrist, Hill, \& Gill, 1998). All this leaves obvious traces in the animal's organs that can be verified during post-mortem inspection. Liver abscesses are detected only at the time of slaughter, because cattle, even those that carry hundreds of small abscesses or several large abscesses, seldom exhibit any clinical signs (Nagaraja \& Chengappa, 1998). On the other hand, rumenitis lesions may serve as "timeless" pathological sequela and indicators of past chemical insults to ruminal epithelium (Rezac et al., 2014). Although there are logistical challenges to conducting pathologic examination of the rumen at chain speed in modern packing plants (Llonch et al., 2015), there are a several advantages to including rumen lesion data in conjunction with liver abscess data when monitoring ruminal health in a production system or evaluating interventions. Nevertheless, the methods and scoring systems must be well documented and consistent, and data collection must be complied over time to establish baseline or "normal" ranges (Brown et al., 1975; Rezac et al., 2014; Amachawadi \& Nagaraja, 2016). 


\subsection{Key indicators and future considerations}

Animal welfare is an essential part of any agroecosystem. Animal production systems have always taken into account the welfare of the animals. What is new is that the concept of animal welfare has now been redefined and includes aspects (previously little considered), such as the possibility of expressing natural behaviour or the absence of negative emotional states. Therefore, current animal welfare assessment systems must take into account these new animal needs and include appropriate indicators (valid, reliable and viable) that allow to assess the physical and mental welfare of the animals. Increasing world trade associated with a growing demand for animal protein has increased the number of cattle raised, transported and slaughtered, also increasing welfare problems at various points in the supply chain (Miranda-de la Lama, 2013). As welfare is a multi-dimensional concept, it makes sense to use a multi-criteria aggregation system to assess it (Czycholl, Kniese, Schrader, \& Krieter, 2017). Even though there are limitations to using CWI at slaughter plants, they could greatly improve handling by reducing stress and pain caused by poor management (Grandin, 2017). Assessment of welfare is critical to animal management, welfare surveillance, enforcement of legislation, compliance with farm assurance schemes, and welfare labelling. Along those lines, "iceberg" or "key" indicators provide an overall assessment of welfare, just as the protruding tip of an iceberg signals its submerged bulk beneath the water's surface' (FAWC, 2009). If these indicators provide reliable information about the welfare state of animals, assessments could be limited to those specific measures, and the time taken for an assessment could be reduced accordingly (Heath, Browne, Mullan, \& Main, 2014).

In this context, meat inspection is one of the most widely implemented and longest running systems of surveillance. Its primary objective is to identify animals that are not fit for human consumption and to remove their carcasses and offal from the food chain. Additional objectives are to support animal disease control and, more recently, to identify and prosecute animal welfare issues (Stärk et al., 2014). Several authors have proposed the use of a complete set of indicators to benchmark the prevalence of CWI to inform risk-based selection for inspections measuring compliance with animal welfare legislation (Støier, Larsen, Aaslyng, \& Lykke, 2016). Nevertheless, both the cost and the simplicity of the assessment must be taken into account. Since meat inspection is also a resource-consuming activity, the use of key indicators has been proposed as a useful tool to provide a picture of the overall welfare of the animal and function as a warning signal for underlying problems. Provided they are shown to be valid and feasible, key indicators could substitute the current large set of measures used in welfare assessment (FAWC, 2009). An integrated system based on the use of key indicators defined for each inspection step with the setting of alarm thresholds could be implemented. This type of system enables a complete traceability of a processed batch with the record of alarm signals raised during the meat inspection process and of the management measures applied (Stärk et al., 2014).

Assessing the welfare of animals in general, while aiming for objectivity and using quantitative measures, is not entirely value free. Animal welfare is a concept that admits moral values and other more emotional preferences (Heleski \& Anthony, 2012). Animal welfare scientist must comply with the moral values of society in order to generate sustainable approaches to animal welfare management ( $\mathrm{Ohl} \&$ van der Staay, 2012; Ferguson, Schreurs, Kenyon, \& Jacob, 2014). Recently, instrumental and sensory meat qualities have also been correlated with ethical quality, i.e. aspects of animal welfare that may be compromised during the production process (Webster, 2001). In this context, it will be necessary to inform consumers and the meat industry that the ethical value of a product is an element of growing economic importance and an increasing business opportunity (Miranda-De la Lama, Villarroel, \& María, 2014). Attention to those factors may help avoid the appearance of technical barriers to global beef trade in the future (Pighin et al.,
2013). Finally, it is worth mentioning that although animal welfare in European and English-speaking abattoirs has been evaluated and reported broadly, such data are relatively sparse in other countries. The way animals are managed and processed outside European and Englishspeaking markets can be markedly different in terms of scale of production, infrastructure, market requirements, the availability of manual labor and technology. As a result, research in those regions is necessary (Doyle et al., 2016; Njisane \& Muchenje, 2017).

\section{Conclusions}

Knowledge of potential synergies and trade-offs between CWI and voluntary monitoring systems for value chain is essential for meat industry who aim to improve the level of welfare and the meat quality at pre-slaughter commercial operations. This review can serve as a tool that provides very useful indicators; however, it is also important to note that there may be variations on the effectiveness of these indicators among regions (e.g. developed vs developing world), and even in the same country (e.g. export plant vs municipal abattoirs). Even though the production of meat has become more efficient and line speeds have increased, there is still room for improvement throughout the pre-slaughter logistic chain. This systematic review identifies highly valid indicators that are useful to assess cattle welfare at abattoirs, including body condition score, human-animal interactions, vocalizations, carcass bruising and meat $\mathrm{pH}$. In addition, some intermediate valid indicators (i.e., respiratory rate, body temperature, and DFD meat) are useful and should be investigated further. Data collection at commercial abattoirs can help to improve procedures. In general, information along the food chain could be used much more systematically to provide a basis for a more-risk-based meat inspection.

\section{Conflict of interest}

All authors declare that there are no present or potential conflicts of interest among the authors and other people or organizations that could inappropriately bias their work.

\section{Acknowledgements}

This study was funded by the Mexican Council for Science and Technology (CONACyT), project CB-2015-259327 for Metropolitan Autonomous University (UAM-Lerma). Many thanks to the CONACyT and National Autonomous University of Mexico (UNAM), for Scholarship PhD Program for Natyieli Losada-Espinosa.

\section{References}

Alende, M., Volpi Lagreca, G., Pordomingo, A., Pighín, D., Grigioni, G., Garduza, F., .. Sancho, A. (2014). Effects of transport, lairage and ageing time on stress indicators and on instrumental and sensory quality of beef from steers. Archivos de Medicina Veterinaria, 46(2), 217-227.

Amachawadi, R., \& Nagaraja, T. (2016). Liver abscesses in cattle: A review of incidence in Holsteins and of bacteriology and vaccine approaches to control in feedlot cattle. Journal of Animal Science, 94(4), 1620-1632.

Amtmann, V., Gallo, C., van Schaik, G. \& Tadich. N. (2006). Relationships between antemortem handling, blood based stress indicators and carcass $\mathrm{pH}$ in steers. Archivos de Medicina Veterinaria, 38(3), 259-264.

Anderson, B., \& Horder, J. (1979). The Australian carcass bruises scoring. Queensland Agricultural Journah, 105(2), 281-287.

Apple, J. (1999). Influence of body condition score on live and carcass value of cull beef cows. Journal of Animal Science, $77(10), 2610-2620$.

Apple, J., Davis, J., Stephenson, J., Hankins, J., Davis, J., \& Beaty, S. (1999). Influence of body condition score on carcass characteristics and subprimal yield from cull beef cows. Journal of Animal Science, $77(10), 2660-2669$.

Atkinson, S., Velarde, A., \& Algers, B. (2013). Assessment of stun quality at commercial slaughter in cattle shot with captive bolt. Animal Welfare, 22(4), 473-481.

Averós, X., Martín, S., Riu, M., Serratosa, J., \& Gosálvez, L. (2008). Stress response of extensively reared young bulls being transported to growing-finishing farms under Spanish summer commercial conditions. Livestock Science, 119(1-3), 174-182.

Barington, K., \& Jensen, H. (2016). The impact of force on the timing of bruises evaluated in a porcine model. Journal of Forensic and Legal Medicine, 40(May), 61-66. 
Barnett, J., \& Hemsworth, P. (1990). The validity of physiological and behavioura measures of animal welfare. Applied Animal Behoviour Science, 25(1-2), 177-187. Bennett, R. M. (1997). Farm animal welfare and food policy. Food Policy, 22(4), 281-288.

Blanco, M., Casasús, I., \& Palacio, J. (2009). Effect of age at weaning on the physiological stress response and temperament of two beef cattle breeds. Animal, 3(January), 108-117.

Boles, J., Kohlbeck, K., Meyers, M., Perz, K., Davis, K., \& Thomson, J. (2015). The use of blood lactate concentration as an indicator of temperament and its impact on growth rate and tenderness of steaks from Simmental $\times$ Angus steers. Meat Science 103(May), 68-74.

Bourguet, C., Deiss, V., Gobert, M., Durand, D., Boissy, A., \& Terlouw, E. (2010) Characterising the emotional reactivity of cows to understand. Applied Animal Behaviour Science, 125(1-2), 9-21.

Bourguet, G., Deiss, V., Cohen Tannugi, G., \& Terlouw, E. (2011). Behavioural and physiological reactions of cattle in a commercial abattoir: Relationships with organisational aspects of the abattoir and animal characteristics. Meat Science, 88(1), $158-168$

Breuer, K., Hemsworth, P., Barnett, J., Matthews, L., \& Coleman, G. (2000). Behavioural response to humans and the productivity of commercial dairy cows. Applied Animal Behaviour Science, 66(4), 273-288.

Broom, D. (1986). Indicators of poor welfare. British Veterinary Joumal, 142, 524-526.

Broom, D. (1988). The scientific assessment of animal welfare. Applied Animal Behaviour Science, 20(1-2), 5-19.

Broom, D. (1991). Assessing welfare and suffering. Behavioural Processes, 25(2-3), $117-123$

Broom, D. (2003). Transport stress in cattle and sheep with details of physiological, ethological and other indicators. Deutsche Tierärstiche Wochenschrift, 110(3), 83-88.

Brown, H., Bing, R., Grueter, H., McAskill, J., Cooley, C., \& Rathmacher, R. (1975). Tylosin and chlortetracycline for the prevention of liver abscesses, improved weight gains and feed efficiency in feedlot cattle. Joumal of Animal Science, 40(2), 207-213.

Burdick, N., Carroll, J., Hulbert, L., Dailey, J., Willard, S., Vann, R., ... Randel, R. (2010). Relationships between temperament and transportation with rectal temperature and serum concentrations of cortisol and epinephrine in bulls. Livestock Science, 129(1-3), 166-172.

del Campo, M., Brito, G., Soares de Lima, J., Hernández, P., \& Montossi, F. (2010). Finishing diet, temperament and lairage time effects on carcass and meat quality traits in steers. Meat Science, 86(4), 908-914.

CHILE (1994). Ministerio de Agricultura. Reglamento sobre funcionamiento de mataderos, cámaras frigorificas y centrales de desposte y fija equipamiento mínimo de tales establecimientos. Decreto No 342. Publicado en Diario Oficial del 22 de enero de 1994.

Chulayo, A.. \& Muchenje, V. (2015). A balanced perspective on animal welfare for improved meat and meat products: A review. South African Journal of Animal Science, $45(5), 452-469$.

Chulayo, A., Bradley, G., \& Muchenje, V. (2016). Effects of transport distance, lairage time and stunning efficiency on cortisol, glucose, HSPA1A and how they relate with meat quality in cattle. Meat Science, 117, 89-96.

Clark, B., Stewart, G. B., Panzone, L. A., Kyriazakis, I., \& Frewer, L. J. (2017). Citizens, consumers and farm animal welfare: A meta-analysis of willingness-to-pay studies. Food Policy, 68, 112-127.

Cook, N., Hess, J., Foy, M., Bennett, T., \& Brotzman, R. (2016). Management characteristics, lameness, and body injuries of dairy cattle housed in high-performance dairy herds in Wisconsin. Journat of Dairy Science, 99(7), 1-13.

Coopman, F., De Smet, S., Laevens, H., Van Zeveren, A., \& Duchateau, L. (2009). Live weight assessment based on easily accessible morphometric characteristics in the double-muscled Belgian Blue beef breed. Livestock Science, 125(2-3), 318-322.

Corah, L. R. (1989). Body condition - An indicator of the nutritional status of beef cows. Agri-Practice, 10(4), 25-28.

Correia-Gomes, G., Smith, R., Fze, J. Henry, M., Gunn, G., Williamson, S., \& Tongue, S. (2016). Pig abattoir inspection data: Can it be used for surveillance purposes? PLOS One, 11(8), e0161990.

Correia-Gomes, C., Eze, J. I., Borobia-Belsué, J., Tucker, A. W., Sparrow, D., Strachan, D., \& Gunn. G. J. (2017). Voluntary monitoring svstems for pig health and welfare in the UK: Comparative analysis of prevalence and temporal patterns of selected non-respiratory post mortem conditions. Preventive Veterinary Medicine, 146, 1-9.

Cruz-Monterrosa, R., Reséndiz-Cruz, V., Rayas-Amor, A., López, M., \& Miranda-de la Lama, G. (2017). Bruises in beef cattle at slaughter in Mexico: Implications on quality, safety and shelf life of the meat. Tropical Animal Health and Production, 49(1), $145-152$.

Czycholl, I., Kniese, C., Schrader, L., \& Krieter, J. (2017). Assessment of the multi-criteria evaluation system of the welfare quality ${ }^{\oplus}$ protocol for growing pigs. Animal, 21, 1-8.

Dalmau, A., Temple, D., Rodríguez, P., Llonch, P., \& Velarde, A. (2009). Application of the welfare quality ${ }^{\oplus}$ protocol at pig slaughterhouses. Animal Welfare, 18(November), $497-505$.

Dawkins, M. (1998). Evolution and animal welfare. The Quarterly Review of Biology, 73(3), 305-328.

Doyle, R. Coleman, G., McGill, D., Reed, M., Ramdani, W., \& Hemsworth, P. (2016). Investigating the welfare, management and human-animal interactions of cattle in four Indonesian abattoirs. Animal Welfare, 25(2), 191-197.

Duarte, M., Paulino, P. Fonseca, M., Diniz, L., Cavali, J, Seräo, N., . Cox, R. (2011). Influence of dental carcass maturity on carcass traits and meat quality of Nellore bulls. Meat Science, $88(3), 441-446$.

Duncan, I. (2005). Science-based assessment of animal welfare: Farm animals. Revue scientifique et technique-Office international des epizooties, 24(2), 483.

Edwards-Callaway, L., Calvo-Lorenzo, M., Scanga, J., \& Grandin, T. (2017). Mobility scoring of finished cattle. Vet Clin Food Anim, 33, 235-250.

Emenheiser, J., Tait, R., Jr. Shackelford, S., Kuehn, L., Wheeler, T., Notter, D., \& Lewis, R.
(2014). Use of ultrasound scanning and body condition score to evaluate composition traits in mature beef cows. Journal of Animal Science, 92(9), 3868-3877.

FAWC (2009). Farm animal welfare in great Britain: Past, present and future. London: FAWC.

Ferguson, D., \& Warner, R. (2008). Have we underestimated the impact of pre-slaughter stress on meat quality. Meat Science, $80(1), 12-19$.

Ferguson, D., Schreurs, N., Kenyon, P., \& Jacob, R. (2014). Balancing consumer and societal requirements for sheep meat production: An Australasian perspective. Meat Science, 98(3), 477-483.

Ferreira, G., Andrade, C., Costa, F., Freitas, M., Silva, T., \& Santos, I. (2006). Effects of transport time and rest period on the quality of electrically stimulated male cattle carcasses. Meat Science, 74(3), 459-466.

Francisco, C., Resende, F., Benatti, J., Castilhos, A., Cooke, R., \& Jorge, A. (2015). Impacts of temperament on Nellore cattle: Physiological responses, feedlot performance, and carcass characteristics. Journal of Animal Science, 93(11), 5419-5429.

Galindo, M., \& Manteca, V. (2012). Scientific assessment of animal welfare. In R. Mota, H Maris, I. Guerrero, \& M. Trujillo (Eds.). Animal Welfare Productivity and quality of the meat (pp. 13-24). Mexico: Elsevier.

Gallo, G., Espinoza, M., \& Gasic, J. (2001). Effects of 36 hours road transport with or without a resting period on live weigh and some meat quality aspects in cattle. Archivos de Medicina Veterinaria, 33(1), 43-53.

Gallo, C., Teuber, C., Cartes, M., Uribe, H., \& Grandin, T. (2003). Improvements in stunning of cattle with a pneumatic stunner after changes in equipment and employee training. Archivos de Medicina Veterinaria, 35(2), 159-170.

Giannetto, C., Fazio, F., Casella, S., Marafioti, S., Giudice, E., \& Piccione, G. (2011). Acute phase protein response during road transportation and lairage at a slaughterhouse in feedlot beef cattle. Journal of Veterinary Medical Science, 73(11), 1531-1534.

Gibson, T., Dadios, N., \& Gregory, N. (2015). Effect of neck cut position on time to collapse in halal slaughtered cattle without stunning. Meat Science, 110(December), 310-314.

Grandin, T. (1998). The feasibility of using vocalization scoring as an indicator of poor welfare during cattle slaughter. Applied Animal Behaviour Science, 56(2-4), 121-128.

Grandin, T. (2001). Cattle vocalizations are associated with handling and equipment problems at beef slaughter plants. Applied Animal Behaviour Science, 71(3), 191-201.

Grandin, T. (2010). Auditing animal welfare at slaughter plants. Meat Science, 86(1), 56-65.

Grandin, T. (2015). Improving Animal Welfare: A Practical Approach (2nd ed.). U.K.: Cabi.

Grandin, T. (2017). On-farm conditions that compromise animal welfare that can be monitored at the slaughter plant. Meat Science, 132, 52-58.

Grandin, T., \& Shivley, G. (2015). How farm animals react and perceive stressful situations such as handling, restraint, and transport. Animals, 5(4), 1233-1251.

Gregory, N., Lee, C., \& Widdicombe, J. (2007). Depth of concussion in cattle shot by penetrating captive bolt. Meat Science, 77(4), 499-503.

Halachmi, I., Klopcic, M., Polak, P., Roberts, D., \& Bewley, J. (2013). Automatic assessment of dairy cattle body condition score using thermal imaging. Computers and Electronics in Agriculture, 99(November), 35-40.

Harley, S., More, S., Boyle, L., \& O' Connell, N., \& Hanlon, A. (2012, June 27). Good animal welfare makes economic sense: Potential of pig abattoir meat inspection as a welfare surveillance tool. Retrieved from Irish Veterinary Journal https:// irishvetjournal.biomedcentral.com/articles/10.1186/2046-0481-65-11.

Hayes, N., Schwartz, C., Phelps, K., Borowicz, P., Maddock-Carlin, K., \& Maddock, R. (2015). The relationship between pre-harvest stress and the carcass characteristics of beef heifers that qualified for kosher designation. Meat Science, 100(February), $134-138$.

Heath, G. A. E., Browne, W. J., Mullan, S., \& Main, D. C. J. (2014). Navigating the iceberg: Reducing the number of parameters within the Welfare Quality assessment protocol for dairy cows. Animal, 8(12), 1978-1986.

Heleski, C., \& Anthony, R. (2012). Science alone is not always enough: The importance of ethical assessment for a more comprehensive view of equine welfare. Journal of Veterinary Behavior, 7(3), 169-178.

Hemsworth, P. (2003). Human-animal interactions in livestock production. Applied Animal Behaviour Science, $81(3), 185-198$.

Hemsworth. P., Rice, M., Karlen, M., Calleja, L., Barnett, J., Nash, J., \& Coleman, G. (2011). Human-animal interactions at abattoirs: Relationships between handling and animal stress in sheep and cattle. Applied Animal Behaviour Science, 135(1-2), 24-33.

Hill, B., Mc Manus, A. Brown, N., Playford, C. \& Noble, J, (2000), A bovine stress syndrome associated with exercise-induced hyperthermia. Australian Veterinary Journal, $78(1), 38-43$.

Hoffman, L., \& Lithl, J. (2012). Causes of cattle bruising during handling and transport in Namibia. Meat Science, 92(2), 115-124.

Hoinville, L., Alban, L., Drewe, J., Gibbens, J., Gustafson, L., Häsler, B., ... Stärk, K. (2013). Proposed terms and concepts for describing and evaluating animal-health surveillance systems. Preventive Veterinary Medicine, 112(1-2), 1-12.

Honkavaara, M., Rintasalo, E., Ylonen, J., \& Pudas, T. (2003). Meat quality and transport stress of cattle. Deutsche Tierärztliche Wochenschrift, 110(3), 125-128.

Hou, X., Liang, R., Mao, Y., Zhang, Y., Niu, L., Wang, R., ... Luo, X. (2014). Effect of suspension method and aging time on meat quality of Chinese fattened cattle $\mathrm{M}$ Longissimus dorsi. Meat Science, 96(1), 640-645.

Huertas, S., Gil, A., Piaggio, J., \& van Eerdenburg, F. (2010). Transportation of beef cattle to slaughterhouses and how this relates to animal welfare and carcase bruising in an extensive production system. Animal Welfare, 19(August), 281-285.

Hultgren, J., Wiberg, S., Berg, G., Cvek, K., \& Lunner Kolstrup, G. (2014). Cattle behaviours and stockperson actions related to impaired animal welfare at Swedish slaughter plants. Applied Animal Behaviour Science, 152(March), 23-37.

[INN] Instituto Nacional de Normalización, Chile (2002). Canales de Bovino - Definiciones y tipificación. Norma Chilena Oficial NCH. 1306. Of. 93.

Ingenbleek, P., Harvey, D., Ilieski, V., Immink, V., de Roest, K., \& Schmid, O. (2013). The 
European market for animal-friendly products in a societal context. Animals, 3(3), 808-829.

Irivine, R. (2015). A conceptual study of value chain analysis as a tool for assessing a veterinary surveillance system for poultry in Great Britain. Agricultural Systems, 135(May), 143-158.

Jacobsen, S., Pedersen, J., \& Tolboll, T. (2003). Indicators of stress in slaughter cattle with short and long pre-slaughter transportation. Acta Veterinaria Scandinavica, 44(1), 289.

Jarvis, A., Harrington, D., \& Cockram, M. (1996). Effect of source and lairage on some behavioural and biochemical measurements of feed restriction and dehydration in cattle at a slaughterhouse. Applied Animal Behaviour Science, 50(1), 83-94.

Jeleníková, J., Pipek, P., \& Staruch, L. (2008). The influence of ante-mortem treatment on relationship between $\mathrm{pH}$ and tenderness of beef. Meat Science, 80(3), 870-874.

Kamatara, K., Mpairwe, D. Christensen, M., Eskildsen, C.. Mutetikka, D., Muyonga, J.. Madsen, J. (2014). Influence of age and method of carcass suspension on meat quality attributes of pure bred Ankole bulls. Livestock Science, 169(November), 175-179.

von Keyserlingk, M., Barrientos, A., Ito, K., Galo, E., \& Weary, D. (2012). Benchmarking cow comfort on North American freestall dairies: Lameness, leg injuries, lying time. facility design, and management for high-producing Holstein dairy cows. Joumal of Dairy Science, 95(12), 7399-7408.

Kim, G.-D.. Lee, H.-S., Jung, E.-Y., Lim, H.-J., Seo, H.-W., Lee, Y.-H., ... Yang, H.-S. (2013). The effects of $\mathrm{CO}_{2}$ gas stunning on meat quality of cattle compared with captive bolt stunning. Livestock Science, 157(1), 312-316.

King, D., Schuehle Pfeiffer, C., Randel, R., Welsh, T., Jr., Oliphint, R., Baird, B., ... Savell, J. (2006). Influence of animal temperament and stress responsiveness on the carcass quality and beef tenderness of feedlot cattle. Meat Science, 74(3), 546-556.

Kreikemeier, K., Unruh, J., \& Eck, T. (1998). Factors affecting the occurrence of darkcutting beef and selected carcass traits in finished beef cattle. Journal of Animal Science, 76(2), 388-395.

Kristensen, L., Støier, S., Würtz, J., \& Hinrichsen, L. (2014). Trends in meat science and technology: The future looks bright, but the journey will be long. Meat Science, 98(3), 322-329.

Langlois, N. E. I. (2007). The science behind the quest to determine the age of bruises - A review of the English language literature. Forensic Science, Medicine, and Pathology, 3, $241-251$.

Lensink, B., Fernandez, X., Boivin, X., Pradel, P., Le Neindre, P., \& Veissier, I. (2000). The impact of gentle contacts on ease of handling, welfare, and growth of calves and on quality of veal meat. Joumal of Animal Science, 78(5), 1219-1226.

Lensink, B., Fernandez, X., Cozzi, G., Florand, L., \& Veissier, I. (2001). The influence of farmers' behavior on calves' reactions to transport and quality of veal meat. Journal of Animal Science, 79(3), 642-652.

Ljungberg, D., Gebresenbet, G., \& Aradom, S. (2007). Logistics chain of animal transport and abattoir operations. Biosystems Engineering, 96(2), 267-277.

Llonch, P., King, E., Clarke, K., Downes, J., \& Green, L. (2015). A systematic review of animal based indicators of sheep welfare on farm, at market and during transport and qualitative appraisal of their validity and feasibility for use in UK abattoirs. The Veterinary Journal, 206(3), 289-297.

Mach, N., Bach, A., Velarde, A., \& Devant, M. (2008). Association between animal, transportation, slaughterhouse practices, and meat pH in beef. Meat Science, $78(3)$, $232-238$.

María, G. A. (2008). Meat quality. Long distance transport and welfare of farm animals (pp. 77-112). Oxfordshire, UK: CAB International.

María, G. A. (2017). Bienestar animat: Apuntes de asignatura. Zaragoza, España: Facultad de Veterinaria, Universidad de Zaragoza.

María, G., Villarroel, M., Sañudo, G., Olleta, J., \& Gebresenbet, G. (2003). Effect of transport time and ageing on aspects of beef quality. Meat Science, 65(4), 1335-1340.

María, G., Villarroel, M., Chacón, G., \& Gebresenbet, G. (2004). Scoring system for evaluating the stress to caftle of commercial loading and unloading. Veterinary Record, 154(26), 818-821.

McGregor, B. (2017). Relationships between live weight, body condition, dimensional and ultrasound scanning measurements and carcass attributes in adult Angora goats. Small Ruminant Research, 147(February), 8-17.

McNally, P., \& Warriss, P. (1996). Recent bruising in cattle at abattoirs. The Veterinary Record, 10(March), 126-128.

Minka, N., \& Ayo, J. (2007). Effects of loading behaviour and road transport stress on traumatic injuries in cattle transported by road during the hot-dry season. Livestock Science, 107(1), 91-95.

Minka, N., \& Ayo, J. (2009). Physiological responses of food animals to road transportation stress. African Journal of Biotechnology, 8(25), 7415-7427.

Miranda-de la Lama, G. (2013). Transport and pre-slaughter logistics: Definitions and current tendencies in animal welfare and meat quality. Veterinaria México, 44(1), $31-56$.

Miranda-de la Lama, G., Leyva, I., Barreras-Serrano, A., Pérez-Linares, C., Sánchez-López, E., María, G., \& Figueroa-Saavedra, F. (2012). Assessment of cattle welfare at a commercial slaughter plant in the northwest of Mexico. Tropical Animal Health and production, 44(3), 497-504.

Miranda-de la Lama, G., Pascual-Alonso, M., Guerrero, A., Alberti, P., Alierta, S., Sans, P., ... María, G. (2013). Influence of social dominance on production, welfare and the quality of meat from beef bulls. Meat Science, 94(4), 432-437.

Miranda-De la Lama, G., Villarroel, M., \& María, G. (2014). Livestock transport from the perspective of the pre-slaughter logistic chain: A review. Meat Science, 98(1), 9-20.

Miranda-de la Lama, G. C., Estévez-Moreno, L. X., Sepúlveda, W. S., Estrada-Chavero, M. C. Rayas-Amor, A. A., Villarroel, M., \& María. G. A. (2017). Mexican consumers' perceptions and attitudes towards farm animal welfare and willingness to pay for welfare friendly meat products. Meat Science, 125, 106-113.

Miranda-de la Lama, G. C., Salazar-Sotelo, M. I., Pérez-Linares, C., Figueroa-Saavedra, F., Villarroel, M., Sañudo, C., \& Maria, G. A. (2012). Effects of two transport systems on lamb welfare and meat quality. Meat Science, 92(4), 554-561.

Morris, S., Kenyon, P., \& Burnham, D. (2002). A comparison of two scales of body condition scoring in Hereford x Friesian beef breeding cows. Proceedings of the New Zealand Grasstand Association, 64, 121-123 (West Coast).

Mounier, L., Dubroeucq, H., Andanson, S., \& Veissier, I. (2006). Variations in meat pH of beef bulls in relation to conditions of transfer to slaughter and previous history of the animals. Journal of Animal Science, 84(6), 1567-1576.

Mpakama, T., Chulayo, A., \& Muchenje, V. (2014). Bruising in slaughter cattle and its relationship with Creatine kinase levels and beef quality as affected by animal related factors. Asian-Australasian Journal of Animal Sciences, 27(5), 717-725.

Mpamhanga, C., \& Wotton, S. (2015). The effects of pre-slaughter restraint (for the purpose of cattle identification) on post-slaughter responses and carcass quality following the electrical stun/killing of cattle in a Jarvis Beef stunner. Meat Science, 107(September), 104-108.

Muñoz, D., Strappini, A., \& Gallo, C. (2012). Animal welfare indicators to detect problems in the cattle stunning box. Archivos de Medicina Veterinaria, 44(3), 297-302.

Nagaraja, T., \& Chengappa, M. (1998). Liver abscesses in feedlot cattle: A review. Journal of Animal Science, 76(1), 287-298.

NAMI (2016). North American meat institute mobility scoring system. Retrieved from NAMI https://www.youtube.com/watch?v5QIslfHCvkpg.

Nanni Costa, L., Lo Fiego, D., Tassone, F., \& Russo, V. (2006). The relationship between carcass bruising in bulls and behaviour observed during pre-slaughter phases. Veterinary Research Communications, 30(1), 379-381.

Neves, J., Paranhos da Costa, M., Roça, R., Faucitano, L., \& Gregory, N. (2016). A note comparing the welfare of Zebu cattle following three stunning-slaughter methods. Meat Science, 117(July), 41-43.

Nicholson, M., \& Sayers, A. (1987). Relationships between body weight, condition score and heart firth changes in Boran cattle. Tropical Animal Health and Production, 19(2), $115-120$.

Njisane, Y., \& Muchenje, V. (2017). Farm to abattoir conditions, animal factors and their subsequent effects on cattle behavioural responses and beef quality - A review. Asian-Australasian Journal of Animal Sciences, 30(6), 755-764.

Ohl, F., \& van der Staay, F. (2012). Animal welfare: At the interface between science and society. The Veterinary Journal, 192(1), 13-19.

Okada, K., Takemura, K., \& Sato, S. (2013). Investigation of various essential factors for optimum infrared thermography. Journal of Veterinary Medical Science, 75(10), 1349-1353.

O'Neill, H., Webb, E., Frylinck, L., \& Strydom, P. (2012). Urinary catecholamine concentrations in three beef breeds at slaughter. South African Journal of Animal Science, $42(5), 545-549$.

Onenc, A. \& Kaya, A. (2004). The effects of electrical stunning and percussive captive bolt stunning on meat quality of cattle processed by Turkish slaughter procedures. Meat Science, 66(1), 809-815.

Owens, F., Secrist, D., Hill, W., \& Gill, D. (1998). Acidosis in cattle: A review. Journal of Animal Science, 76(1), 275-286.

Panjono, Kang, S., Lee, I., \& Lee, S. (2009). Carcass characteristics of Hanwoo (Korean cattle) from different sex conditions, raising altitudes and slaughter seasons. Livestock Science, 123(2-3), 283-287.

Pascual-Alonso, M., Miranda-de la Lama, G., Aguayo-Ulloa, L., Villarroel, M., Mitchell, M., \& María, G. (2017). Thermophysiological, haematological, biochemical and behavioural stress responses of sheep transported on road. Journal of Animal Physiology and Animal Nutrition, 101(3), 541-551.

Peña, F., Avilés, C., Domenech, V., González, A., Martínez, A., \& Molina, A. (2014). Effects of stress by unfamiliar sounds on carcass and meat traits in bulls from three continental beef cattle breeds at different ageing times. Meat Science, 98(4), 718-725.

Pérez-Linares, G., Figueroa-Saavedra, F., \& Barreras-Serrano, A. (2008). Management factors associated to DFD meat in bovine on desertic climate. Archivos de Zootecnia, $57(220), 545-547$.

Pérez-Linares, C., Sánchez-López, E., Ríos-Rincón, F., Olivas-Valdéz, J., FigueroaSaavedra, F., \& Barreras-Serrano, A. (2013). Pre and post slaughter cattle and carcass management factors associated to presence of DFD beef in the hot season. Reyista Mexicana de Ciencias Pecuarias, 4(2), 149-160.

Pérez-Linares, C., Figueroa-Saavedra, F., Estrada-Angulo, A., Sánchez-López, E., BarrerasSerrano, A., Bolado-Sarabia, J., \& Ríos-Rincón, F. (2015). Animal welfare índicators during the stunning of bovines slaughtered in federal inspection type slaughterhouses located in northwestern Mexico. Archivos de medicina veterinaria, 47(3), 375-380.

Phythian, C., Hughes, D., Michalopoulou, E., Cripps, P., \& Duncan, J. (2012). Reliability of body condition scoring of sheep for cross-farm assessments. Small Ruminant Research, 104(1-3), 156-162.

Pighin, D., Davies, P., Grigioni, G., Pazos, A., Ceconi, I., Mendez, D., ... Gonzalez, C (2013). Effect of slaughter handling conditions and animal temperament on bovine meat quality markers. Archivos de Zootecnia, 62(239), 399-409.

Pilling, M. L., Vanezis, P., Perrett, D. F., \& Johnston, A. (2010). Visual assessment of the timing of bruising by forensic experts. Journal of Forensic and Legal Medicine, 17(3), $143-149$.

Piñeiro, M., Pineiro, C., Carpintero, R., Morales, J., Campbell, F., Eckersall, P., ... Lampreave, F. (2007). Characterization of the pig acute phase protein response to road transport. Veterinary Journal, 173(3), 669-674.

Probst, J., Spengler Neff, A., Hillmann, E., Kreuzer, M., Koch-Mathis, M., \& Leiber, F. (2014). Relationship between stress-related exsanguination blood variables, vocalisation, and stressors imposed on cattle between lairage and stunning box under conventional abattoir conditions. Livestock Science, 164(June), 154-158.

Rabasa, C., \& Dickson, S. (2016). Impact of stress on metabolism and energy. Current Opinion in Behavioral Sciences, 9 (June), 71-77.

Rezac, D., Thomson, D., Bartle, S., Osterstock, J., Prouty, F., \& Reinhardt, C. (2014) Prevalence, severity, and relationships of lung lesions, liver abnormalities, and rumen 
health scores measured at slaughter in beef cattle. Journal of Animal Science, 92(6), $2595-2602$.

Ribeiro, J., Gonçalves, T., Ladeira, M., Tullio, R., Campos, F., Bergmann, J., ... de Carvalho, J. (2012). Reactivity, performance, color and tenderness of meat from zebu cattle finished in feedlot. Revista Brasileira de Zootecnia, 41(4), 1009-1015.

Romero, M., Uribe-Velásquez, L., Sánchez, J., \& Miranda-de la Lama, G. (2013). Risk factors influencing bruising and high muscle $\mathrm{pH}$ in Colombian cattle carcasses due to transport and pre-slaughter operations. Meat Science, 95(2), 256-263.

Romero, M., Uribe-Velásquez, L., Sánchez, J., Rayas-Amor, A., \& Miranda-de la Lama, G. (2017). Conventional versus modern abattoirs in Colombia: Impacts on welfare. Meat Science, 123, 173-181.

Rostagno, M. (2009). Can stress in farm animals increase food safety risk? Foodborne Pathogens and Disease, 6(7), 767-776.

Rushen, J. (2003). Changing concepts of farm animal welfare: Bridging the gap between applied and basic research. Applied Animal Behaviour Science, 81(3), 199-214.

Rushen, J., de Pasillé, A., von Keyserlingk, M., \& Weary, D. (2008). The welfare of cattle Dordrecht, The Netherlands: Springer.

Sandström, V. (2017). Development of a monitoring system for the assessment of cattle welfare in abattoirs. Retrieved fromSwedish University of Agricultural Scienceswww.hmh. slu.se.

Sant'Anna, A., \& Paranhos da Costa, M. (2013). Validity and feasibility of qualitative behavior assessment for the evaluation of Nellore cattle temperament. Livestock Science, 157(1), 254-262.

Sapolsky, R., Romero, M., \& Munck, A. (2000). How do glucocorticoids influence stress responses? Integrating permissive, suppressive, stimulatory and preparative actions. Endocrine Reviews, 21(1), 55-89.

Scanga, J., Belk, K., Tatum, J., Grandin, T., \& Smith, G. (1998). Factors contributing to the incidence of dark cutting beef. Journal of Animal Science, 76(8), 2040-2047.

Schwartzkopf-Genswein, K., Booth-McLean, M., Abid Shah, M., Entz, T., Joan Bach, S., John Mears, G., ... Angus McAllister, T. (2007). Effects of pre-haul management and transport duration on beef calf performance and welfare. Applied Animal Behaviour Science, 108(1-2), 12-30.

Shaw, F., \& Tume, R. (1992). The assessment of pre-slaughter and slaughter treatments of livestock by measurement of plasma constituents-a review of recent work. Meat Science, 32(3), 311-329.

Simova, V., Voslarova, E., Vecerek, V., Passantino, A., \& Bedanova, I. (2016). Effects of travel distance and season of the year on transport-related mortality in cattle. Animal Science Journal. http://dx.doi.org/10.1111/asj.12658.

van Staaveren, N., Doyle, B., Manzanilla, E., Galderón Díaz, J., Hanlon, A., \& Boyle, L. (2017). Validation of carcass lesions as indicators for on-farm health and welfare of pigs. Journal of Animal Science, 95(4), 1528-1536.

Stärk, K., Alonso, S., Dadios, N., Dupuy, C., Ellerbroek, L., Georgiev, M., ... Lindberg, A. (2014). Strengths and weaknesses of meat inspection as a contribution to animal health and welfare surveillance. Food ControL, 39(May), 154-162.

Støier, S., Larsen, H., Aaslyng, M., \& Lykke, L. (2016). Improved animal welfare, the right technology and increased business. Meat Science, 120(October), 71-77.

Strappini, A., Metz, J., Gallo, C., \& Kemp, B. (2009). Origin and assessment of bruises in beef cattle at slaughter. Animal, 3(5), 728-736.

Strappini, A., Frankena, K., Metz, J., Gallo, B., \& Kemp, B. (2010). Prevalence and risk factors for bruises in Chilean bovine carcasses. Meat Science, 86(3), 859-864.

Tadich, N., Gallo, C., Bustamante, H., Schwerter, M., \& van Schaik, G. (2005). Effects of transport and lairage time on some blood constituents of Friesian-cross steers in Chile. Livestock Production Science, 93(3), 223-233.

Tadich, N., Gallo, C. Brito, M., \& Broom, D. (2009). Effects of weaning and $48 \mathrm{~h}$ transport by road and ferry on some blood indicators of welfare in lambs. Livestock Science, $127(1), 132-136$

Tebug, S., Missohou, A., Sabi, S., Juga, J., Poole, E., Tapio, M., \& Marshall, K. (2016). Using body measurements to estimate live weight of dairy cattle in low-input systems in Senegal. Journal of Applied Animal Research. http://dx. doi.org/10.1080/09712119. 2016.1262265
Teke, B., Akdag, F., Ekiz, B., \& Ugurlu, M. (2014). Effects of different lairage times after long distance transportation on carcass and meat quality characteristics of Hungarian Simmental bulls. Meat Science, 96(1), 224-229.

Terlouw, C. (2005). Stress reactions at slaughter and meat quality in pigs: Genetic background and prior experience: $\mathrm{A}$ brief review of recent findings. Livestock Production Science, 94(1), 125-135.

Terlouw, C. (2015). Stress reactivity, stress at slaughter and meat quality. In W. Przybylski, \& D. Hopkins (Eds.). Meat quality: Genetic and environmental factors (pp. 199-217). Philadelphia, USA: CRC Press.

Thomson, U., Loneragan, H., Henningson, N., Ensley, S., \& Bawa, B. (2015). Description of a novel fatigue syndrome of finished feedlot cattle following transportation. Joumal of the American Veterinary Medical Association, 247(1), 66-72.

Trevisi, E., \& Bertoni, G. (2009). Some physiological and biochemical methods for acute and chronic stress evaluation in dairy cows. Italian Joumal of Animal Science, 8(1), $265-286$.

Van de Water, G., Verjans, F., \& Geers, R. (2003). The effect of short distance transport under commercial. Livestock Production Science, 82(2-3), 171-179.

Vial, F., \& Reist, M. (2014). Evaluation of Swiss slaughterhouse data for integration in a syndromic surveillance system. Retrieved from BMC Veterinary Research https:// bmcvetres.biomedcentral.com/articles/10.1186/1746-6148-10-33.

Villarroel, M., María, G., Sañudo, C., García-Belenguer, S., Chacón, G., \& Gebresenbet, G. (2003a). Effect of commercial transport in Spain on cattle welfare and meat quality. DTW. Deutsche Tierarztliche Wochenschrift, 110(3), 105-107.

Villarroel, M., María, G., Sañudo, C., Olleta, J., \& Gebresenbet, G. (2003b). Effect of transport time on sensorial aspects of beef meat quality. Meat Science, 63(3), $353-357$.

Vimiso, P., \& Muchenje, V. (2013). A survey on the effect of transport method on bruises, $\mathrm{pH}$ and colour of meat from cattle slaughtered at a South African commercial abattoir. South African Journal of Animal Science, 43(1), 105-111.

Visser, E., van Reenen, C., Hopster, H., Schilder, M., Knaap, J., Barneveld, A., \& Blokhuis, H. (2001). Quantifying aspects of young horses' temperament: Consistency of behavioural variables. Applied Animat Behaviour Science, 74(4), 241-258.

Voisinet, B., Grandin, T., O'Connor, S., Tatum, J., \& Deesing, M. (1997). Bos Zndicus-cross feedlot cattle with excitable temperaments have tougher meat and a higher incidence of borderline dark cutters. Meat Science, 46(4), 361-377.

Waiblinger, S., Menke, C., Korff, J., \& Bucher, A. (2004). Previous handling and gentle interactions affect behaviour and heart rate of dairy cows during a veterinary procedure. Applied Animal Behaviour Science, 85(1-2), 31-42.

Wangchuk, K., Wangdi, J., \& Mindu, M. (2017). Comparison and reliability of techniques to estimate live cattle body weight. Journal of Applied Animal Research. http://dx.doi. org/10.1080/09712119.2017.1302876.

Warriss, P., Kestin, S., Brown, S., \& Wilkins, L. (1984). The time required for recovery from mixing stress in young bulls and the prevention of dark cutting beef. Meat Science, 10(1), 53-68.

Waynert, D., Stookey, J., Schwartzkopf-Genswein, K., Watts, J., \& Waltz, G. (1999). The response of beef cattle to noise during handling. Applied Animal Behaviour Science, $62(1), 27-42$.

Webster, A. (2001). Farm animal welfare: The five freedoms and the free market. The Veterinary Joumal, 161(3), 229-237.

Weeks, C. (2008). A review of welfare in cattle, sheep and pig lairages, with emphasis on stocking rates, ventilation and noise. Animal Welfare, 17, 275-284.

Welfare Quality (2009). Welfare quality assessment protocol for caute. Lelystad, Netherlands: Welfare Quality Consortium.

Werner, M., Hepp, G., Soto, C., Gallardo, P., Bustamante, H., \& Gallo, C. (2013). Effects of a long distance transport and subsequent recovery in recently weaned crossbred beef calves in southern Chile. Livestock Science, 152(1), 42-46.

Yazdanbakhsh, O., Zhou, Y., \& Dick, S. (2017). An intelligent system for livestock disease surveillance. Information Sciences, 378(February), 26-47.

Zinpro Corporation (2016). Step-up locomotion scoring system. Retrieved from Zinpro Corporationhttp://www.zinpro.com/lameness/beef/locomotion-scoring. 